\title{
Evaluation of a specific starter for the production of semi-hard goat's milk cheese
}

\author{
T Requena *, MA De la Fuente, P Fernández de Palencia, \\ M Juárez, C Peláez
}

Instituto del Frio (CSIC), Ciudad Universitaria, 28040 Madrid, Spain

(Received 14 January 1992; accepted 26 June 1992)

\begin{abstract}
Summary - Eight wild-type strains belonging to lactococci, lactobacilli or leuconostoc species were tested as starter cultures in the production of semi-hard goat's milk cheese. The screening of the strains in cheesemaking was in a laboratory scale production. Eleven batches were produced using a combination of the strains in different proportions as starters. Two control batches were made, one from raw milk without starter and another from pasteurized milk with a commercial starter. The strains used in the cheeses that received the best scores in the laboratory scale production were assayed in a pilot scale cheesemaking process. The control batch was produced from raw milk without starter. The starter containing Lactococcus lactis subsp lactis IFPL 359, Lactobacillus casei subsp casei IFPL 731, Lactobacillus plantarum IFPL 935, Leuconostoc mesenteroides subsp dextranicum IFPL 709 and Leuconostoc paramesenteroides IFPL 705 provided the cheeses with the best characteristics after $60 \mathrm{~d}$ of ripening. Lactococci were the most abundant flora in the cheeses, and lactobacilli attained high counts on conclusion of ripening. The cheeses presented nitrogen fractions higher than in the control. The experimental cheeses displayed small, evenly-distributed openings and were awarded maximum scores for flavor, texture and general acceptability.
\end{abstract}

goat's milk cheese / starter cultures / lactic acid bacteria / cheese ripening

Résumé - Évaluation d'un levain spécifique pour la fabrication d'un fromage de chèvre à pâte semi-dure. Huit souches sauvages de lactocoques, de lactobacilles et de leuconostocs ont été testées en tant que levain pour la fabrication de fromages de chèvre à pâte semi-dure. L'étude des souches, dans un premier temps, a été réalisée au laboratoire. Onze levains, composés de différents mélanges des 8 souches, ont été utilisés pour la fabrication de fromages. Deux fabrications témoins, l'une à base de lait cru sans levain et l'autre à base de lait pasteurisé ensemencé avec un levain du commerce, ont aussi été réalisées. Après évaluation de la qualité des fromages obtenus, les meilleurs levains ont été testés à l'échelle pilote. Le levain contenant les souches Lactococcus lactis subps lactis IFPL 359, Lactobacillus casei subsp casei IFPL 731, Lactobacillus plantarum IFPL 935, Leuconostoc mesenteroides subsp dextranicum IFPL 709 et Leuconostoc paramesenteroides IFPL 705 a donné les meilleurs fromages, après $60 j$ d'affinage. À l'issue de la période d'affinage, la flore de ces fromages était composée en majorité de lactocoques. Les lactobacilles étaient aussi très

\footnotetext{
- Present address (January-December 1992): University of Minnesota, Department of Food Science and Nutrition, 1334 Eckles Avenue, St Paul, MN 55108, USA.
} 
abondants. La fraction azotée était plus importante dans les fromages expérimentaux que dans les fromages témoin. Les fromages obtenus avec ce levain avaient une ouverture petite et régulière, un goût et une texture optimales et, en général, étaient de qualité supérieure.

\section{fromage de chèvre / levain lactique / affinage du fromage}

\section{INTRODUCTION}

In Spain, there are still large numbers of highly-regarded traditional cheeses, differing appreciably in characteristics from those manufactured using pasteurized milk with non-specific commercial starters (Marcos, 1987). In order to obtain cheeses presenting characteristics like those of cheeses made with raw milk, the beneficial microorganisms destroyed in heat treatment of the milk must be restored. Furthermore, by studying and characterizing this lactic flora, it should be possible to obtain basic information essential to understanding the mechanisms through which they act in the cheese, thus providing a basis for selection as starter cultures.

In an attempt to develop an appropriate starter for the production of goat's milk cheese, we have studied the lactic acid bacteria responsible for the ripening of a cheese made from raw goat's milk (Fontecha et al, 1990; Requena et al, 1991; Requena et al, unpublished data). The aim of this work was to assess these lactic bacteria as a starter for production of a semihard goat's milk cheese.

\section{MATERIALS AND METHODS}

\section{Microorganisms and cheeses}

The microorganisms used as cheese starter cultures in this work were previously isolated from milk, curds and 'Majorero', a traditional Spanish cheese, as described by Fontecha et al (1990). Eight strains out of 182 were selected (table I) according to the technological aptitude characteristics described by Requena et al (1991), and were combined in varying proportions (table II) to provide the starters which were used to produce 16 batches of cheeses.

The screening of the strains in cheesemaking was in a laboratory-scale production and 11 experimental batches were produced. The first 7 batches (L11 to L17) were made from pasteurized goat's milk in July, using a combination of the strains in varying proportions as starters (table II). Two control batches were also made, one using a commercial starter type 0 (Redi-Set 96, Chr Hansen, Copenhagen, Denmark), batch $\mathrm{L} 18 \mathrm{c}$, and another using raw milk without starter (batch L19c). A second set of laboratory batches, identified as L2, were produced in November, using as starters those used in the cheeses assigned with the highest score in the L1 cheesemaking (batches L21 and L22), and batch $L 23$ using new strains. The control batch was made from raw milk without starter (L24C). The last cheesemaking process was pilot scale (identified as P) and selection of the microorganisms to use as starter was related to the results obtained from laboratory scale production and

Table I. Microorganisms used as starters in this study.

Microorganismes composant les levains étudiés.

Strain

Lactococcus lactis subsp lactis $\quad$ IFPL 359

IFPL 361

L lactis subsp lactis var diacetylactis IFPL 915

Lactobacillus casei subsp casei IFPL 731

IFPL 936

L plantarum IFPL 935

Leuconostoc paramesenteroides IFPL 705

L mesenteroides subsp dextranicum IFPL 709 
Table II. Composition of the starters used in the cheese production (L: laboratory scale; P: pilot scale).

Composition des levains utilisés au cours des fabrications fromagères ( $L$ : essais laboratoire; $P$ : essais pilote).

\section{Batch}

\section{Starter (proportion of strains)}

\begin{tabular}{|c|c|c|}
\hline L11 & IFPL $361(100 \%$ & \\
\hline L12 & IFPI 361 (90\%) & + IFPL $915(10 \%)$ \\
\hline L13 & IFPL 361 (90\%) & + IFPI $709(10 \%)$ \\
\hline L14 & $\begin{array}{l}\text { IFPL } 361(90 \%) \\
\text { IFPL } 705(5 \%)\end{array}$ & + IFPL $709(5 \%)$ \\
\hline L15 & IFPL $361(90 \%)$ & + IFPL $731(10 \%)$ \\
\hline L16 & $\begin{array}{l}\text { IFPL } 361(90 \%) \\
\text { IFPL } 936(5 \%)\end{array}$ & + IFPL $731(5 \%)$ \\
\hline L17 & $\begin{array}{l}\text { IFPI } 361(90 \%) \\
\text { IFPL } 709(2,5 \% \\
\text { IFPL } 936(2.5 \%\end{array}$ & $\begin{array}{l}\text { + IFPL } 915(2.5 \%) \\
\text { + IFPL } 731(2.5 \%)\end{array}$ \\
\hline L18 & $\begin{array}{l}\text { Chr Hansen O: } \\
\text { L lactis cremoris }\end{array}$ & $\begin{array}{l}\text { lactis lactis } \\
(95-98 \%)\end{array}$ \\
\hline 19 & Raw milk withou & it starter \\
\hline
\end{tabular}

L21 IFPL $361(80 \%)+$ IFPL $709(10 \%)+$ IFPL $705(10 \%)$

L22 IFPL $361(80 \%)+$ IFPI $705(10 \%)+$ IFPL $936(10 \%)$

L23 IFPL $359(80 \%)+$ IFPL $709(5 \%)+$ IFPL $705(5 \%)$ + IFPL $731(5 \%)+$ IFPL 935 (5\%)

L24c Raw milk without starter

$\begin{array}{ll}\text { P1 } & \text { IFPL } 359(80 \%)+\text { IFPL } 709(10 \%)+ \\ & \text { IFPI } 705(10 \%) \\ \text { P2 } & \text { IFPL } 359(80 \%)+\text { IFPL 709 (5\%) + } \\ & \text { IFPL 705 (5\%) + IFPL 731 (5\%) + } \\ & \text { IFPL 935 (5\%) } \\ \text { P3C } & \text { Raw milk without starter }\end{array}$

c: control batch.

c: témoin

after a study of the proteolytic system of the lactococci and lactobacilli strains (Requena et al, unpublished data). This production was made in March and approximately 18 months after first laboratory scale cheese manufacturing. The control batch (P3c) was made from raw milk without starter.

The strains contained in each starter were inoculated together in sterile skimmed milk at a final concentration of $1 \%$ (approximately $7 \mathrm{log}$ cfu/ml) and incubated at $22{ }^{\circ} \mathrm{C}$ until a pH between 4.6 and 4.7 was attained (approximately $16 \mathrm{~h}$ ).

All batches of pasteurized milk cheese were prepared adding $1 \%$ concentration of the different starters to pasteurized goat's milk $\left(65^{\circ} \mathrm{C}\right.$, $30 \mathrm{~min}$ for the laboratory batches, L1 and L2, and $75{ }^{\circ} \mathrm{C}, 15 \mathrm{~s}$ for the pilot batches, $\mathrm{P}$ ), containing $0.2 \mathrm{~g} / \mathrm{l}$ of $\mathrm{CaCl}_{2}$ and animal rennet $(0.1$ $\mathrm{g} / \mathrm{l}$ of a rennet $\mathrm{F}=1: 75000$, Chr Hansen). After milk coagulation, the curd was cut, reheated to $37^{\circ} \mathrm{C}$ and scooped into cylindrical moulds. After pressing, the curd was salted in brine $(20 \%$ $\mathrm{NaCl}$ ) at $4{ }^{\circ} \mathrm{C}$ for $3 \mathrm{~h}$ in the laboratory batches, and $16 \mathrm{~h}$ in the pilot batches. From each laboratory batch, cheeses of about $400 \mathrm{~g}$ were obtained, and covered with paraffin. From each pilot batch, 9 cheeses of approximately $1 \mathrm{~kg}$ were produced. The cheeses were ripened for 60 days at $10-12{ }^{\circ} \mathrm{C}$ and $85-90 \%$ relative humidity and samples were taken for physicochemical and microbiological analyses. Further samples of raw milk, pasteurized milk and curds, as well as milk samples with each starter culture added for the pilot samples were taken for microbiological analysis. For these latter batches, sampling and analyses were performed in triplicate.

\section{Microbiological analysis}

Sampling and dilutions were performed in accordance with International Dairy Federation (IDF) standards (1985). Counts of total viable microorganisms, lactobacilli, leuconostocs and coliforms were determined by the methods previously described by Gómez et al (1989). The lactococci counts were determined on $\mathrm{M}-17$ agar (Terzaghi and Sandine, 1975) incubated for $48 \mathrm{~h}$ at $30^{\circ} \mathrm{C}$.

\section{Physical and chemical analysis}

Determination of $\mathrm{pH}$, total solids, protein and total nitrogen was carried out in all cheeses as de- 
scribed by Alonso et al (1987). Salt content was determined in pilot batches according to the same authors. Non-casein nitrogen (NCN) and non-protein nitrogen (NPN) were determined by the method of Kuchroo and Fox (1982). Amine nitrogen $\left(\mathrm{N}-\mathrm{NH}_{2}\right)$ was determined in pilot cheeses by the method of Kuchroo et al (1983).

The casein fraction was studied in pilot cheeses by polyacrylamide gel electrophoresis according to the method of Ramos et al (1977). Electrophoresis was performed at $15 \mathrm{~mA}$ constant current for about $3 \mathrm{~h}$ in a Hoëfer model SE400 slab gel electrophoresis (Hoëfer, Scientific Instruments, San Francisco, USA). Band staining was performed with Coomassie blue R-250 (Merck, Darmstadt, Germany). Quantitative analyses of the casein fractions obtained in the gels was performed using a Shimadzu densitometer (Shimadzu Corp, Kyoto, Japan) comprising a double-wavelength spectrophotometer (Chromato Scanner C5-930) and a graphic printing integration system (Data Recorder DR-2).

The composition of the free fatty acid fraction (FFA) was analyzed by gas chromatography in pilot cheese samples at the end of the ripening period (60 d) (Martin-Hernández et al, 1988), using a Perkin-Elmer model 8420 chromatograph (Perkin Elmer Co, Beaconsfield, UK), equipped with a programmed temperature vaporizer (PTV) injector.

Lactose was analyzed by gas chromatography in pilot cheeses at 2 and $30 \mathrm{~d}$ ripening (Olano et al, 1986). A Perkin-Elmer model Sigma $3 \mathrm{D}$ chromatograph was used.

\section{Sensory analysis}

Sensory analysis was performed at the conclusion of the ripening period, following the recommendations of IDF standards (1987), by a panel composed of 15 tasters from the laboratory. The attributes judged were appearance, aroma, flavor/taste, texture and general acceptability, with scoring on the following scale: 1 . very poor; 2 , poor; 3 fair; 4 , good; and 5 , very good. Presence of certain characteristics responsible for the appearance of defects was also evaluated.

\section{Statistical analysis}

Unifactorial analysis of variance was performed with the results from pilot cheese samples. The level of significance was set at $99 \%$.

\section{RESULTS AND DISCUSSION}

\section{Laboratory cheese production}

Sensorial analysis results of L1 laboratory scale cheeses were determinant of following productions. Batch control (L19c), produced from raw milk, was awarded the highest score (4.2), pointing up characteristically cheesy flavor/taste and displaying well-distributed interior openings. All experimental cheeses and control batch L18c (made using a commercial starter) received medium scores $(3.2 \pm 0.3)$. Defects of these cheeses were the lack of typical cheesy aroma, appearance of bitter and acid flavor/taste, and a crumbly, 'sandy' texture. The acid flavor developed by experimental cheeses could be related to fast initial lactic acid production by microorganisms used as starter, and this could be associated with the appearance of bitter flavor (Lee et al, 1990). In relation to acid development, $L$ lactis subsp lactis IFPL 361 , a component of all experimental starter cultures of production L1, showed a high acid-production activity in preliminary characterization assays (Requena et al, 1991). Batch $L 12$, with the presence of $L$ lactis subsp lactis var diacetylactis IFPL 915 in the starter, showed an unusual "buttery' flavor. Within experimental cheeses, batch $\mathrm{L} 14$ received the highest score due to an agreeable creamy texture.

Because acidification was the major problem, a new laboratory test was. performed in which the starter culture composition was modified (table II). The propor- 
tion of $L$ lactis subsp lactis IFPL 361 was reduced to $80 \%$ (batches $L 21$ and $L 22$ ). $A$ new lactococcal strain was used: $L$ lactis subsp lactis IFPL 359 (batch L23). Due to the low score in the commercial starter used as control in production L1, only a raw milk made cheese was used as control (L24c).

The results of total viable counts, lactococci, lactobacilli, leuconostocs, as well as $\mathrm{pH}$ during ripening period of the cheeses from the elaboration L2 are shown in table III. Total viable counts in raw milk and after pasteurization were 7 and 3.9 log cfu/ml, respectively. This initial flora was composed mainly of lactococci $(7 \mathrm{log}$ $\mathrm{cfu} / \mathrm{ml}$ ); lactobacilli and leuconostoc levels were similar (4 log cfu/ml). Neither of these groups were detected in pasteurized milk.
Batches L21 and L22, produced with $L$ lactis subsp lactis IFPL 361 in the starter, showed a maximum of total viable and lactococci counts after 2 days of ripening. In the batch $L 23$, containing $L$ lactis subsp lactis IFPL 359 in the starter, and L24C control batch, lactococci attained maximum after 30 days of ripening (table III).

Initial $\mathrm{pH}$ of milk was 6.6 , and after 2 days of ripening the $\mathrm{pH}$ declined in all 4 batches (table III), with the drop being most marked in batches L21 and L22, which contained the lactococcal strain with higher acidification activity (Requena et al, 1991).

The values of nitrogen fractions increased during the ripening period in all 4 batches. The control batch (L24c) attained the highest proteolysis index containing $41.22 \%$ of NCN (\%TN), of which $56.06 \%$ was NPN.

Table III. Log counts (log cfu/g) of total viable microorganisms, lactococci, lactobacilli and leuconostocs, and $\mathrm{pH}$ in cheese during ripening (2, 30 and $60 \mathrm{~d})$. Laboratory scale production (L2).

Dénombrements (log ufc/g) de la flore totale, des lactocoques, lactobacilles et leuconostocs, et pH du fromage au cours de l'affinage (2, 30 et 60 jours). Essais laboratoire (L2).

\begin{tabular}{lclllll}
\hline Batch & $\begin{array}{c}\text { Ripening } \\
\text { time }\end{array}$ & $\begin{array}{l}\text { Total viable } \\
\text { counts }\end{array}$ & Lactococci & Lactobacilli & Leuconostocs & $p H$ \\
\hline \multirow{2}{*}{ L21 } & 2 & 9.09 & 9.10 & - & 7.67 & 5.34 \\
& 30 & 8.85 & 8.51 & - & 8.15 & 5.14 \\
& 60 & 7.82 & 7.78 & - & 7.04 & 5.18 \\
L22 & 2 & 9,25 & 9.14 & 7.74 & 7.76 & 5.35 \\
& 30 & 8.96 & 8.92 & 8.34 & 8.12 & 5.15 \\
& 60 & 8.48 & 8.44 & 8.42 & 6.30 & 5.12 \\
L23 & 2 & 9.18 & 9.23 & 7.85 & 7.61 & 5.64 \\
& 30 & 9.23 & 9.09 & 8.23 & 8.15 & 5.24 \\
& 60 & 8.21 & 8.14 & 8.11 & 7.91 & 5.21 \\
L24c & 2 & 9.29 & 9.31 & 5.65 & 7.59 & 5.41 \\
& 30 & 9.31 & 9.37 & 7.11 & 7.95 & 5.32 \\
& 60 & 8.05 & 8.06 & 7.23 & 7.60 & 5.32 \\
\hline
\end{tabular}

$-:<1 \log$ cfu/g; c: control batch.

c : témoin. 
Results of sensory analysis revealed again that the highest score for general acceptability was awarded to the control batch (4.2). Batches L21 and L22 obtained low scores (2.9 and 3.2, respectively), showing acid/bitter flavors and 'sandy' textures, probably due to the fast acid production of the lactococcal strain used in the starter culture. Batch $\mathrm{L} 23$, containing $L$ lactis subsp lactis IFPL 359 , was awarded the highest score after the control batch (3.9), showing similar aroma and flavor characteristics, although slightly inferior, and displaying welldistributed interior openings. This favorable score could be explained by the development of a balanced aroma and flavor due to the presence of a heterogeneous flora and a correct cheese acidification.

\section{Pilot scale production}

Three cheese batches in a pilot scale were prepared (table II): batch P1 was made using a starter composed by lactococci and leuconostocs, batch P2 using the same starter which received the best score in laboratory cheese batches, and batch P3c, used as control, prepared from raw milk without starter. The results of microbiological, physico-chemical and sensory characteristics are described below.

\section{Microbiological characteristics}

Table IV shows the average counts for total viable microorganisms, lactococci, lactobacilli, leuconostocs and coliforms in raw milk, milk with starter culture added, curds and cheese in the course of ripening of batches P1, P2 and P3c.

The total microorganism and coliform counts were high in the raw milk, indicating excessive handling during milking, collection and/or transportation of the milk, which was a mixture from multiple sourc- es. These values were higher than those found by Fontecha et al (1990) in the traditional preparation of Majorero goat's milk cheese. With the addition of the starter, the pasteurized milk attained bacterial flora levels comparable to those found in raw milk, but now comprising selected flora. No coliforms were found in the pasteurized milk, indicating proper heat treatment, although in the milk intended for the preparation of batch P2, post-pasteurization contamination was detected.

Lactococci were the dominant flora throughout the ripening process in all 3 batches of cheeses, attaining maximum after $2 \mathrm{~d}$ of ripening. At that point, the values determined in the batch $P 1$ cheeses were higher $(P<0.01)$. The evolution of these microorganisms was similar to that described by Fernández del Pozo et al (1988) and Poullet et al (1991) in traditionally-made Spanish cheeses.

The presence of lactobacilli in cheese batch $\mathrm{P} 1$ is attributed to contamination occurring in the cheese factory after pasteurization, a frequent phenomenon in cheesemaking (Lee et al, 1990). The lactobacilli in batches $P 2$ and $P 3 c$ reached a maximum in the first month of ripening and maintained values similar to those attained by the leuconostocs thereafter.

Particularly noteworthy were the very high coliform values in the raw-milk cheeses (P3c) at $2 d$ of ripening, although these microorganisms declined sharply thereafter and at the end of the ripening period they stood at approximately $3 \mathrm{log} \mathrm{cfu} / \mathrm{ml}$. No coliform development was found in the P2 cheeses, and these had practically disappeared by the end of ripening.

\section{Physical and chemical characteristics}

Table $\mathrm{V}$ shows the average values of $\mathrm{pH}$, total solids, protein and $\mathrm{NaCl}$ during ripening of the cheese batches P1, P2 and P3c. 
Table IV. Log counts (log cfu/ml or log cfu/g) of total viable microorganisms, lactic acid bacteria and coliforms in raw milk, milk with starter, curd and cheese during ripening $(2,30$ and $60 \mathrm{~d})$. Pilot scale production $(\mathrm{P})$.

Dénombrements (log ufc/ml ou log cfu/g) de la flore totale, des bactéries lactiques et des coliformes dans le lait cru, le lait additionné de levain, le caillé et le fromage au cours de l'affinage (2, 30 et $60 \mathrm{j})$. Essais pilote $(P)$.

\begin{tabular}{ccccccc}
\hline Sample & Batch & $\begin{array}{c}\text { Total viable } \\
\text { counts }\end{array}$ & Lactococci & Lactobacilli & Leuconostocs & Coliforms \\
\hline Raw milk & & 7.66 & 7.21 & 5.70 & 5.49 & 5.42 \\
Milk with & & & & & & \\
starter & P1 & 7.66 & 7.62 & $<1$ & 5.95 & $<1$ \\
& P2 & 7.33 & 7.29 & 5.71 & 5.54 & 2.93 \\
Curd & P1 & 8.40 & 8.47 & $<1$ & 6.73 & $<1$ \\
& P2 & 8.30 & 8.24 & 6.57 & 6.41 & 4.13 \\
& P3c & 8.42 & 8.18 & 6.46 & 6.57 & 6.64 \\
Cheese & & & & & & \\
2 days & P1 & 9.56 & 9.62 & $<1$ & 8.05 & $<1$ \\
& P2 & 9.07 & 9.06 & 7.26 & 7.23 & 4.48 \\
& P3c & 9.25 & 9.27 & 7.82 & 7.97 & 7.47 \\
30d & P1 & 8.72 & 8.50 & 4.19 & 7.52 & $<1$ \\
& P2 & 9.08 & 8.85 & 7.75 & 7.50 & 3.87 \\
& P3c & 8.78 & 8.67 & 8.16 & 8.16 & 5.22 \\
& P1 & 8.17 & 8.20 & 4.36 & 7.20 & $<1$ \\
$60 \mathrm{~d}$ & P2 & 7.80 & 7.80 & 7.44 & 6.99 & 0.73 \\
& P3c & 8.52 & 8.42 & 8.07 & 7.47 & 3.06 \\
& & & & & & \\
\hline
\end{tabular}

c: control batch.

c : témoin.

After $2 \mathrm{~d}$ of ripening, $\mathrm{pH}$ declined in all 3 batches by approximately 1 unit with respect to the $\mathrm{pH}$ of the milk, which was 6.6. During this period, the $\mathrm{pH}$ of cheese batch $\mathrm{P} 1$ was lower $(P<0.01)$ than in the other batches. This is interpreted as a consequence of the higher lactococci counts found in these cheeses. In addition, the initial lactose content of these cheeses was lower (674 mg/100 $\mathrm{g}$ cheese) than in batch P2 (697 $\mathrm{mg} / 100 \mathrm{~g})$, and even more so than in batch P3c $(975 \mathrm{mg} / 100 \mathrm{~g})$. In all 3 batches, $\mathrm{pH}$ continued to decline and at the end of the ripening period stood at about 5.4. These values were in agreement with those found in goat's milk cheeses (Marcos et al, 1984; Fontecha et al, 1990; Martin-Hernández et al, 1990).

Total solids and average protein content were similar in all 3 batches of cheeses and were within the limits found for goat's milk cheeses (Martin-Hernández et al, 
Table V. Mean values (means of 9 cheese samples) and SD for the gross composition, pH, total solids (TS), protein (\% TS), $\mathrm{NaCl}\left(\% \mathrm{H}_{2} \mathrm{O}\right)$ and $\mathrm{ni}$ trogen fractions in cheeses during ripening $(2,30$ and $60 \mathrm{~d})$. Pilot scale production $(\mathrm{P})$.

Valeurs moyennes (moyennes de 9 échantillons de fromage) et écarts-type pour la composition globale, le pH, la matière sèche totale (TS), la teneur en protéines (\% TS), $\mathrm{NaCl}\left(\% \mathrm{H}_{2} \mathrm{O}\right)$ et les fractions azotées du fromage au cours de l'affinage $(2,30$ et $60 \mathrm{j})$. Essais pilote $(\mathrm{P})$.

\begin{tabular}{|c|c|c|c|c|c|c|c|c|}
\hline Batch & $\begin{array}{l}\text { Ripening } \\
\text { time (d) }\end{array}$ & $p H$ & $\begin{array}{l}\text { TS } \\
\text { (\%) }\end{array}$ & $\begin{array}{c}\text { Protein } \\
\text { (\% TS) }\end{array}$ & $\begin{array}{c}\mathrm{NaCl} \\
\left(\% \mathrm{H}_{2} \mathrm{O}\right)\end{array}$ & $\begin{array}{c}N C N \\
(\% T N)\end{array}$ & $\begin{array}{c}N P N \\
(\% T N)\end{array}$ & $\begin{array}{l}\mathrm{N}-\mathrm{NH}_{2} \\
(\% \mathrm{TN})\end{array}$ \\
\hline P1 & $\begin{array}{r}2 \\
30 \\
60\end{array}$ & $\begin{array}{l}5.47 \pm 0.03 \\
5.34 \pm 0.04 \\
5.43 \pm 0.04\end{array}$ & $\begin{array}{l}50.00 \pm 0.28 \\
54.34 \pm 0.51 \\
59.99 \pm 0.54\end{array}$ & $\begin{array}{l}37.73 \pm 0.30 \\
37.00 \pm 0.79 \\
36.66 \pm 0.77\end{array}$ & $\begin{array}{l}2.68 \pm 0.05 \\
4.68 \pm 0.52 \\
6.46 \pm 0.26\end{array}$ & $\begin{array}{r}9.69 \pm 0.50 \\
19.44 \pm 0.91 \\
23.88 \pm 0.78\end{array}$ & $\begin{array}{r}4.40 \pm 0.09 \\
13.35 \pm 0.63 \\
17.07 \pm 0.54\end{array}$ & $\begin{array}{l}0.36 \pm 0.03 \\
2.27 \pm 0.21 \\
3.39 \pm 0.33\end{array}$ \\
\hline P2 & $\begin{array}{r}2 \\
30 \\
60\end{array}$ & $\begin{array}{l}5.68 \pm 0.02 \\
5.45 \pm 0.05 \\
5.42 \pm 0.02\end{array}$ & $\begin{array}{l}50.47 \pm 1.49 \\
54.29 \pm 0.84 \\
59.60 \pm 1.80\end{array}$ & $\begin{array}{l}40.00 \pm 1.15 \\
38.47 \pm 1.31 \\
37.46 \pm 0.82\end{array}$ & $\begin{array}{l}1.94 \pm 0.16 \\
4.48 \pm 0.13 \\
6.39 \pm 0.58\end{array}$ & $\begin{array}{r}7.65 \pm 0.38 \\
16.86 \pm 0.56 \\
21.92 \pm 1.10\end{array}$ & $\begin{array}{r}3.27 \pm 0.09 \\
11.31 \pm 0.16 \\
14.65 \pm 0.64\end{array}$ & $\begin{array}{l}0.26 \pm 0.01 \\
1.69 \pm 0.08 \\
2.59 \pm 0.11\end{array}$ \\
\hline P3c & $\begin{array}{r}2 \\
30 \\
60\end{array}$ & $\begin{array}{l}5.77 \pm 0.03 \\
5.50 \pm 0.04 \\
5.47 \pm 0.02\end{array}$ & $\begin{array}{l}50.24 \pm 0.84 \\
55.47 \pm 0.81 \\
59.92 \pm 0.95\end{array}$ & $\begin{array}{l}39.72 \pm 1.51 \\
35.79 \pm 1.35 \\
36.21 \pm 1.19\end{array}$ & $\begin{array}{l}2.15 \pm 0.21 \\
5.40 \pm 0.51 \\
7.92 \pm 0.19\end{array}$ & $\begin{array}{r}7.77 \pm 0.22 \\
15.27 \pm 1.03 \\
20.30 \pm 0.80\end{array}$ & $\begin{array}{r}2.63 \pm 0.07 \\
9.05 \pm 0.31 \\
13.21 \pm 0.31\end{array}$ & $\begin{array}{l}0.22 \pm 0.03 \\
1.24 \pm 0.04 \\
2.16 \pm 0.16\end{array}$ \\
\hline
\end{tabular}


1984) and semi-hard cheeses (Marcos, 1987).

The $\mathrm{NaCl}$ content ( $\%$ moisture) of the cheeses made with raw milk was higher ( $P$ $<0.01$ ) than in cheeses made with starter cultures. The latter had $\mathrm{NaCl}$ values within the limits cited in the literature as providing good sensory attributes (Guinee and Fox, 1987).

\section{Nitrogen fractions}

Table $\mathrm{V}$ also shows the values of NCN, NPN and $\mathrm{N}-\mathrm{NH}_{2}$ (\% TN) in the course of the ripening of cheese batches P1, P2 and $P 3 c$. An increase $(P<0.01)$ was noted in the content of these fractions up to the end of ripening in all 3 batches, the most marked rise being in the first 30 days. The cheeses in the batches made with starter culture presented the highest values. The fact that NCN content was higher in the P1 cheeses from the start of the ripening period may be interpreted as a consequence of greater casein hydrolysis in the initial stages of manufacture of the batch. This was probably caused by greater retention of residual rennet, as the initial $\mathrm{pH}$ in these cheeses was significantly lower. The influence of $\mathrm{pH}$ on the retention of rennet and on the susceptibility of casein to hydrolysis has been discussed by a number of authors (O'Keefe et al, 1975; Visser, 1977). Then again, initial casein hydrolysis in these cheeses could also be related to a greater lactococci development. However, these microorganisms are not the main factor responsible for initial casein hydrolysis in cheeses, their function being essentially to increase $\mathrm{NPN}$ and $\mathrm{N}-\mathrm{NH}_{2}$ production from the casein polypeptides and peptides hydrolyzed from the casein by the rennet (Visser, 1977). Thus, the cheese batch P1 was also found to have a higher NPN and $\mathrm{N}-\mathrm{NH}_{2}$ content during ripening. In this context, it is important to note that the strain Lactococcus lactis subsp lactis IFPL 359, used in the experimental starters, displayed a high level of proteolytic activity on whole casein, was active on isolated caseins and presented a degree of peptidase activity in whole cell suspensions superior to that of lactobacilli (Requena et al, unpublished data). However, with the inclusion of $L$ casei subsp case $i$ IFPL 731 and $L$ plantarum IFPL 935 in the batch $\mathrm{P} 2$ starter culture, higher NPN and $\mathrm{N}-\mathrm{NH}_{2}$ values were expected in comparison to batch P1, noting the greater intracellular peptidase activity found in these microorganisms (Requena et al, unpublished data). That this did not occur in the P2 cheeses may be due to the lack of a decline in the number of viable lactobacilli in batch P2 sufficient to bring about increased intracellular enzyme activity, or at least a significant increase in NPN and N$\mathrm{NH}_{2}$ content. El Soda et al (1981) showed that when free extracts of $L$ casei cells are added to cheese manufacture, ripening is enhanced with respect to addition of an equivalent amount of intact cells. Aly (1990) reported that addition of freezeshocked $L$ casei and $L$ helveticus strains in the manufacture of Ras cheese increased the values of the nitrogen fractions due to the greater susceptibility of these microorganisms to lysis.

The nitrogen fractions are comparable to those found in traditional cheeses with longer ripening periods (Ramos and Martínez-Castro, 1976; Ramos et al, 1982).

\section{Casein degradation}

$\beta$-Casein was only slightly hydrolyzed in all 3 batches, but degradation was greater in batches $\mathrm{P} 1$ and $\mathrm{P} 2$, reaching $10.2 \%$ and $6.3 \%$ (with respect to cheese at 2 d) respectively, by the end of the ripening period. Degradation of $\alpha_{s}$-casein was much more intense than $\beta$-casein and occurred 
faster in the cheeses made with starter culture than in the control, although values at the end of ripening were similar (approximately $70 \%$ ). In most semi-hard uncooked cheeses ripened by lactic bacteria, there is more hydrolysis of $\alpha_{\mathrm{s}}$-casein during ripening, whereas $\beta$-casein remains practically unchanged (Fox, 1989).

\section{Free fatty acids (FFA)}

Table VI shows the average content in the main FFA of the cheese batches P1, $P 2$ and $P 3 c$ at the end of ripening. Total FFA in the raw-milk batch $(12000 \mathrm{mg} / \mathrm{kg}$ ) was higher than in batches $\mathrm{P} 1$ and $\mathrm{P} 2$ (7 422 and $8238 \mathrm{mg} / \mathrm{kg}$ respectively). These levels were comparable to those found by Martín-Hernández et al (1990) in goat's milk cheese. The degree of lipolysis in the cheeses under study may be considered average and is comparable to that presented by mould-ripened cheeses (Woo et al, 1984). The higher FFA content found in the raw-milk batch may be due to the fact that the milk's native lipase is active in the initial stages of ripening and becomes inactive during pasteurization.

\section{Sensory characteristics}

The sensory assessment of batches P1, $\mathrm{P} 2$ and $\mathrm{P} 3 \mathrm{C}$ at the end of ripening is detailed in table VII. Appearance of the cheeses on cutting received very favorable scores. Cheese batches P1 and P2 displayed well-distributed interior openings produced by the leuconostocs added to the starter culture. Raw-milk cheese openings were larger than normal for this type of cheese, probably due to an excess of coliforms at the start of the ripening process. These cheeses were received unfavourably by the tasting panel and scored the lowest in appearance on cutting. Aroma scores were similar for all cheeses, but there were differences in the characteristic cheesy flavor/taste with those having lactobacilli in the starter scoring best. The raw-milk cheeses were found to have a tangy flavor, due to their greater FFA content. The raw-milk cheeses lost points due to a certain degree of saltiness and other abnormal flavor aspects.

Although there were no significant differences, the highest score for general acceptability was awarded to the P2 cheeses. P2 cheese was made with a starter culture containing a mixture of $\mathrm{Lac}$ tococcus, Lactobacillus and Leuconostoc strains, isolated from this type of cheese and therefore specific to it. The P2 cheese strains were instrumental in producing a cheese with a typical appearance, balanced flavor and aroma, and acceptable texture.

Table VI. Mean free fatty acid (FFA) profile (mg/ $\mathrm{kg}$ ) at the end of cheese ripening (60 days). Composition moyenne en acides gras libres (FFA) (en $\mathrm{mg} / \mathrm{kg}$ ) des fromages en fin d'affinage (60 jours).

\begin{tabular}{|c|c|c|c|}
\hline$F F A$ & $P 1$ & $\begin{array}{c}\text { Batches } \\
\text { P2 }\end{array}$ & $P 3 C$ \\
\hline C4 & 209 & 212 & 327 \\
\hline C6 & 190 & 203 & 293 \\
\hline C8 & 222 & 256 & 454 \\
\hline C10 & 823 & 910 & 1648 \\
\hline C12 & 388 & 465 & 561 \\
\hline $\mathrm{C}_{14}$ & 691 & 786 & 927 \\
\hline C16 & 2074 & 2306 & 2846 \\
\hline C18 & 698 & 760 & 1096 \\
\hline C18:1 & 1441 & 1576 & 2738 \\
\hline Total & 7422 & 8238 & 12000 \\
\hline
\end{tabular}

c: control batch.

c : témoin. 
Table VII. Mean values and standard deviation for the sensory characteristics of the cheeses at the end of ripening $(60 \mathrm{~d})$. Pilot scale production $(P)$.

Caractéristiques sensorielles (moyennes et écarts-type) des fromages en fin d'affinage (60 j). Essais pilote $(P)$.

\begin{tabular}{llllll}
\hline Batch & Appearance & Aroma & Flavor & Texture & $\begin{array}{c}\text { General } \\
\text { acceptance }\end{array}$ \\
\hline P1 & $4.0 \pm 0.76$ & $3.4 \pm 0.75$ & $3.1 \pm 0.87$ & $3.4 \pm 0.71$ & $3.3 \pm 0.67$ \\
P2 & $3.8 \pm 0.71$ & $3.3 \pm 0.88$ & $3.4 \pm 0.86$ & $3.6 \pm 0.70$ & $3.6 \pm 0.71$ \\
P3C & $3.5 \pm 0.87$ & $3.4 \pm 0.91$ & $3.2 \pm 0.97$ & $3.5 \pm 0.85$ & $3.1 \pm 0.74$ \\
\hline
\end{tabular}

c: control batch; c : témoin

Differences in scores given to the raw milk cheeses in both the laboratory and pilot scale production were tentatively attributed to the different microbial levels found in the raw milks. In this way, the presence of high microbial counts in the milk and the 2-d-old pilot cheeses of microorganisms such as coliforms, which are usually considered as off-flavor and open texture producers, could be explained. In these situations, which are not uncommon in Mediterranean countries when unpasteurized milk is collected in bulk (Núnez et al, 1984), a heat treatment is necessary and, consequently, the ripening flora must be restored. Strains tested in this work, starter $\mathrm{P} 2$, proved to be the best in pasteurized goat's milk cheeses. Results provide the basis for a proposed starter in semi-hard goat's milk cheese production. However, additional research should be of great value in defining starter importance to production of this kind of cheese.

\section{ACKNOWLEDGMENTS}

We thank from the Comision Interministerial de Ciencia y Tecnologia (Project ALI 91-0387) for financial support for this study.

\section{REFERENCES}

Alonso L, Juárez $M$, Ramos $M$, Martín-Alvarez PJ (1987) Effects of changes during ripening and frozen storage on the physicochemical and sensory characteristics of Cabrales cheeses. Int J Food Sci Technol 22, 525-534

Aly ME (1990) Utilization of freeze-shocked lactobacilli for enhancing flavor development of Ras cheese. Nahrung 34, 329-335

El Soda M, Desmazeaud MJ, Aboudonia S, Kamal N (1981) Acceleration of cheese ripening by the addition of whole cells or cell free extracts from Lactobacillus casei to the cheese curd. Milchwissenschaft 36, 140-142

Fernández del Pozo B, Gaya P, Medina $M$, Rodriguez-Marín MA, Núñez M (1988) Changes in the microflora of La Serena ewe's milk cheese during ripening. $J$ Dairy Res 55, 449-455

Fontecha J, Peláez C, Juárez $M$, Requena $T$, Gómez C, Ramos M (1990) Biochemical and microbiological characteristics of artisanal hard goat's cheese. J Dairy Sci 73, 11501157

Fox PF (1989) Proteolysis during cheese manufacture and ripening. $J$ Dairy $S c i$ 72, 13791400

Gómez R, Peláez C, De la Torre E (1989) Microbiological study of semi-hard goat's milk cheese (Majorero). Int J Food Sci Technol 24, 147-151 
Guinee TP, Fox PF (1987) Salt in cheese: physical, chemical and biological aspects. In: Cheese: Chemistry, Physics and Microbiology. Vol 1: General Aspects (Fox PF, ed) Elsevier Appl Sci Publ, London

International Dairy Federation (1985) Milk and Milk Products. Methods of Sampling. FIL-IDF $50 \mathrm{~B}$

International Dairy Federation (1987) Sensory Evaluation of Dairy Products. FIL-IDF 99A

Kuchroo CN, Fox PF (1982) Soluble nitrogen in Cheddar cheese. Comparison of extraction procedures. Milchwissenschaft 37, 331-335

Kuchroo CN , Rahilly J, Fox PF (1983) Assessment of proteolysis in cheese by reaction with trinitrobenzene sulphonic acid. Ir J Food Sci Technol 7, 129-133

Lee BH, Laleye LC, Simard RE, Holley RA (1990) Influence of homofermentative lactobacilli on physicochemical and sensory properties of Cheddar cheese. J Food Sci 55, 386-390

Marcos A (1987) Spanish and Portuguese cheese varieties. In: Cheese: Chemistry, Physics and Microbiology. Vol 2: Major Cheese Groups (Fox PF, ed) Elsevier Appl Sci Publ, London

Marcos A, Fernández-Salguero J, Esteban MA, León $F$, Alcalá $M$, Beltrán de Heredia $F H$ (1984) El queso de los Ibores: composición química, valor nutritivo y estabilidad. Ind Láct Esp 64, 15-20

Martín-Hernández $C$, Juárez $M$, Ramos $M$ (1984) Producción y características de composicion de la leche y quesos de cabra. Aliment Equipos Tecnol 3, 61-71

Martin-Hernández MC, Alonso $L$, Juárez $M$, Fontecha J (1988) Gas chromatographic method for estimating free fatty acids in cheese. Chromatographia 25, 87-90

Martin-Hernández $C$, Juárez $M$, Ramos $M$, Martin-Alvarez P (1990) Effects of freezing and frozen storage on the physicochemical and sensory characteristics of four types of goat's cheese. $Z$ Lebensm Unters Forsch 190, 325-330

Núñez JA, Chavarri FJ, Núñez M (1984) Psychrotrophic bacterial flora of raw ewes' milk, with particular reference to Gram negative rods. J Appl Bacteriol 57, 23-29

O'Keeffe RB, Fox PF, Daly C (1975) Proteolysis in Cheddar cheese: influence of the rate of acid production during manufacture. I Dairy Res 42, 111-122

Olano A, Calvo MM, Reglero G (1986) Analysis of free carbohydrates in milk using micropacked columns. Chromatographia 21, 538541

Poullet B, Huertas M, Sánchez A, Cáceres P, Larriba G (1991) Microbiology study of Casar de Cáceres cheese throughout ripening. J Dairy Res 58, 231-238

Ramos M, Martínez-Castro I (1976) Étude de la protéolyse du fromage type "Manchego" au cours de l'affinage. Lait 56, 164-176

Ramos M, Martínez-Castro I, Juárez M (1977) Detection of cow's milk in Manchego cheese. J Dairy Sci 60, 870-877

Ramos M, Barneto R, Suárez JA, Iñigo B (1982) Contribution to study of Mahon Cheese. I. Microbiological and biochemical aspects. Chem Mikrobiol Technol Lebensm 7, 167-172

Requena T, Peláez C, Desmazeaud MJ (1991) Characterization of lactococci and lactobacilli isolated from semi-hard goat's cheese. J Dairy Res 58, 137-145

Terzaghi BE, Sandine WE (1975) Improved medium for lactic streptococci and their bacteriophages. Appl Microbiol 29, 807-813

Visser FMW (1977) Contribution of enzymes from rennet, starter bacteria and milk to proteolysis and flavor development in Gouda cheese. 3. Protein breakdown: analysis of the soluble nitrogen and amino acid nitrogen fractions. Neth Milk Dairy J 31, 210-239

Woo AH, Kollodge S, Lindsay RC (1984) Quantification of major free fatty acids in several cheese varieties. J Dairy Sci 67, 874-878 